\section{Breast cancer mortality among patients attending a cancer hospital, Vitoria, ES}

\section{Mortalidade por câncer de mama em hospital de referência em oncologia, Vitória, ES}

Cristina Arthmar Mentz Albrecht' Maria Helena Costa Amorim'

Eliana Zandonade'

Kátia Viana"

\section{Juliana Oliosi Calheiros"II}

'Graduate Program in Collective Health of Universidade Federal do Espírito Santo - Vitória (ES), Brazil.

"Cancer Registry of Santa Rita de Cássia Hospital, Santa Rita de Cássia Hospital Vitória (ES), Brazil.

I"Universidade Federal do Espírito Santo - Vitória (ES), Brazil.

Correspondence: Cristina Arthmar Mentz Albrecht. Rua São Vicente, 352/24, Santa Cecília, CEP: 90630-180, Porto Alegre, RS, Brazil. Email: cristinaamalbrecht@yahoo.com.br

Financial support: Fundação de Amparo à Pesquisa do Espírito Santo, filed under Protocol No. 060/2009.

Conflict of interests: nothing to declare.

\section{Abstract}

This study aimed to investigate the association between mortality of breast cancer women and the social-demographic and clinical characteristics. During the mortality study of 1,086 women diagnosed with breast cancer and treated from 2000 to 2005 at a cancer hospital in the city of Vitória, Espírito Santo, medical records and tumor registration cards were controlled. The Mortality Information System and the Reclink program were used to identify 280 deaths. Patients were classified under death and non-death, and variables percentages were calculated. For variables that showed statistical significance, considering the level of 0.10 , the crude and adjusted odds ratio (OR) were calculated by logistic regression model. There was a correlation between mortality and the following variables: women coming from the Unified Health System $(\mathrm{p}=0.014 ; \mathrm{OR}=2.38)$, negative $\mathrm{c}$-erb B-2 tumor marker $(\mathrm{p}=0.027$; OR $=2.03$ ), advanced (III and IV) staging ( $\mathrm{p}=0.001$; $\mathrm{OR}=6.89$ and $\mathrm{OR}=17.13$, respectively $)$, presence of metastasis $(\mathrm{p}=0.001 ; \mathrm{OR}=$ 18.23) and recurrence $(\mathrm{p}=0.010 ; \mathrm{OR}=3.53)$. Mortality associated with staging underlines the necessity of warning the population about the benefits of early diagnosis of the disease of cancer.

Keywords: Medical oncology. Breast neoplasms. Women's health. Mortality. Risk factors. Brazil. 


\section{Resumo}

O estudo teve como objetivo verificar a associação entre a mortalidade de mulheres com câncer de mama e as características sociodemográficas e clínicas. No estudo de mortalidade de dados secundários de 1.086 mulheres diagnosticadas com câncer de mama, atendidas entre os anos 2000 e 2005 em hospital referência em oncologia na cidade de Vitória, Espírito Santo, houve coleta aos prontuários e às fichas de registro de tumor. Foi utilizado o Sistema de Informação sobre Mortalidade e o programa Reclink versão 3.1.6.3160 para identificar 280 óbitos. As pacientes foram estratificadas nas categorias óbito e não óbito e foram calculados os percentuais das variáveis do estudo. Para as variáveis do estudo que apresentaram significância estatística, considerando o nível de 0,10, foram calculados os Odds ratio (OR) brutos e ajustados pelo modelo de regressão logística. Houve associação entre mortalidade e as variáveis: encaminhamento procedente do Sistema Único de Saúde ( $\mathrm{p}=0,014$; $\mathrm{OR}=2,38)$, marcador tumoral cerb $\mathrm{B}$ negativo $(\mathrm{p}=0,027 ; \mathrm{OR}=2,03)$, estadiamento III e IV $(\mathrm{p}=0,001 ; \mathrm{OR}=6,89$ e $\mathrm{OR}=17,13$, respectivamente), metástase ( $\mathrm{p}=0,001$; $\mathrm{OR}=18,23)$ e recidiva $(\mathrm{p}=0,010 ; \mathrm{OR}=3,53)$. A mortalidade associada ao estadiamento ratifica a necessidade da conscientização da população sobre o diagnóstico precoce da doença.

Palavras-chave: Oncologia. Neoplasias da mama. Saúde da mulher. Mortalidade. Fatores de risco. Brasil.

\section{Introduction}

Cancer has proven to be an increasing occurrence and presents high mortality rates, constituting a public health problem ${ }^{1}$. It has been estimated that, in 2008, 7.6 billion deaths were caused by the disease ${ }^{2}$.

In Brazil, approximately 518,510 new cases of cancer have been estimated for 2012 and, in 2008, the disease was the second leading cause of death in the country ${ }^{3,4}$. For 2012, of the 260,640 new female cancer cases, it is expected that 53,000 correspond to breast cancer. This makes breast cancer the second most common body location of the disease (the first one being non-melanoma skin tumors) ${ }^{4}$.

In southeastern Brazil, authors highlight trends of increased mortality in metropolitan areas ${ }^{5,6}$. In a study conducted in the state of Espírito Santo, in which data from the Mortality Information System from 1980 to 2007 was analyzed, a trend of increased mortality due to breast cancer was identified in all age groups from 30 years $\mathrm{on}^{7}$. Along with the INCA (Brazilian Cancer Institute) estimates for the year 2012 - in which the state capital, Vitória, proved to be the eighth Brazilian capital with the highest gross incidence rate of breast cancer (71.28 per 100 thousand inhabitants) - this information indicates the need for studies that characterize the prevalence of the disease $\mathrm{e}^{4}$.

Data related to mortality are of utmost importance, as they allow the description of the disease's magnitude and impact. In addition, study of this data is important to identify gaps in patient access to health services and to indicate improvements in their treatment. Therefore, this study was aimed at the investigation of the association between mortality among women diagnosed with breast cancer between 2000 and 2005, who received treatment at Santa Rita de Cássia Hospital, and its sociodemographic and clinical characteristics.

\section{Methodology}

A study of mortality was conducted using secondary data, since the medical 
records were considered from the time of diagnosis until the last visit or date of death. Initially, 1,373 case records were collected of patients diagnosed with breast cancer in the period from January 1st, 2000 to December 31st, 2005, who have had been treatment at Santa Rita de Cássia Hospital and had been included in the Hospital Cancer Registry Information System (SIS-RHC) in the same period.

In women with more than one case of primary breast tumor, only the first diagnosed case was considered, since the inclusion of two tumors from the same individual in the study would duplicate registrations of the subject in the research. Cases in which the staging was not informed were excluded, given the importance of the variable in the prognosis of the patient, for a total of 1,086 patients. The clinical staging classification was chosen, since the pathological staging showed low completeness of data.

Information about deaths were observed through the Mortality Information System database, for the period between 2000 and 2009, provided by the Department of Health of the State of Espírito Santo, which includes only deaths registered in that State. Database relation software, RecLink v. 3.1.6.3160 was used for comparing the database of patients with breast tumor and the database mentioned above, which highlighted patients who underwent treatment at the hospital and culminated in death, using the following variables as parameters for comparison between both databases: patient's name, mother's name and date of birth.

The causes of death were considered according to the International Classification of Diseases (ICD-10 - 2nd Version) and were attributed to breast cancer situations, where the underlying cause of death was specified as C50 and its derivatives (C50.1, C50.2 , C50.3, C50.4, C50.5, C50.6, C50.8, C50.9), which refer to tumors in that location.
Data collection occurred in the Hospital Cancer Registry of Santa Rita de Cássia, in Vitória Hospital, Espírito Santo. The institution consists of two High Complexity Oncology Care Centers, as set forth by Ordinance No. 741 of December 19,2005 , and it is also a general hospital, private and philanthropic, for the treatment and care of cancer patients ${ }^{8}$.

Information has been obtained by querying the Registry Files of Tumor and medical records. Collection occurred from January through December, 2010. The variables of interest in the study not covered by this database were constituted by a form, developed by the authors, which included the following items: number of metastases, recurrence rate, estrogen receptor, progesterone receptor, c-erbB-2 tumor marker and p53 tumor marker. The researchers received training in a course conducted by the hospital.

The variables analyzed comprised 16 items that were divided into two categories for better understanding and organization of the analysis. With respect to sociodemographic variables, the following were found: age at diagnosis, skin color, education level, marital status and source of referral. Regarding the clinical characteristics, the following were analyzed: tumor location, laterality, presence of more than one type of primary tumor, histological type, estrogen receptor, progesterone receptor, c-erb-B-2 tumor marker, P53 tumor marker, number of metastasis, recurrence rate and staging.

The patients were stratified in death and non-death categories and the percentage of qualitative variables in the groups considered were calculated. Chi-square tests of association were used. For quantitative variables, the mean, median and standard deviation were calculated. For the study variables that were statistically significant, considering the level of 0.10 , the crude and adjusted oddsratio (OR) were calculated with the logistic regression model. 
The Statistical Package for Social Sciences (SPSS) v. 18.0 was used. The final level of significance was set at $5 \%$.

The study was duly approved by the Research Ethics Committee of the Health Sciences Department of the Universidade Federal do Espírito Santo, as set forth in Resolution No. 196 of October 16, 1996, under the Research Project Protocol No. $226 / 09^{9}$. There is no conflict of interest to declare.

\section{Results}

Table 1 shows the distribution of the number of deaths through the sociodemographic variables: age, race, marital status and educational level. It was observed that the average age of women at diagnosis was 52 years with a mean of 51 years ( $\mathrm{s}=13$ ). Regarding skin color and marital status, $54 \%(\mathrm{n}=582)$ of patients were identified as mulatto and $44 \%(\mathrm{n}=468)$ were considered white, and most (55\%) were married. About 437 cases of women with incomplete primary education were verified. The Greater Vitória Metropolitan Region held 67\% ( $\mathrm{n}=685)$ of cases, concentrating $75 \%(n=210)$ of deaths in relation to this variable. In addition, patients referred from SUS represented $67 \%(n=621)$ of all cases and $75 \%(n=180)$ of the deaths occurred in this category. Only the educational level $(\mathrm{p}=0.0129)$ and

Table 1 - Distribution of deaths according to socio-demographic variables of women diagnosed with breast cancer and treated at Santa Rita de Cássia Hospital from January 2000 to December 2005.

Tabela 1 - Distribuição dos óbitos segundo variáveis sociodemográficas das mulheres com câncer de mama diagnosticadas e atendidas no Hospital Santa Rita de Cássia no período de janeiro de 2000 a dezembro de 2005.

\begin{tabular}{|c|c|c|c|c|c|c|c|}
\hline \multirow{3}{*}{ Categories } & \multicolumn{6}{|c|}{ Patient's situation } & \multirow{3}{*}{$\mathrm{p}$-value } \\
\hline & \multicolumn{2}{|c|}{ Non-death } & \multicolumn{2}{|c|}{ Death } & \multicolumn{2}{|c|}{ Total } & \\
\hline & $\mathrm{n}$ & $\%$ & $\mathrm{n}$ & $\%$ & $\mathrm{n}$ & $\%$ & \\
\hline \multicolumn{8}{|l|}{ Age group (in years) } \\
\hline$\leq 39$ & 107 & 13 & 46 & 16 & 153 & 14 & \multirow{4}{*}{0.2091} \\
\hline $40-49$ & 254 & 31 & 71 & 25 & 325 & 30 & \\
\hline $50-69$ & 360 & 45 & 130 & 47 & 490 & 45 & \\
\hline$\geq 70$ & 85 & 11 & 33 & 12 & 118 & 11 & \\
\hline \multicolumn{8}{|l|}{ Skin color } \\
\hline White & 362 & 45 & 106 & 38 & 468 & 44 & \multirow{5}{*}{0.1513} \\
\hline Black & 10 & 1 & 4 & 1 & 14 & 1 & \\
\hline Yellow & 0 & 0 & 1 & 0 & 1 & 0 & \\
\hline Mulatto & 420 & 53 & 162 & 60 & 582 & 54 & \\
\hline Indigenous & 7 & 1 & 3 & 1 & 10 & 1 & \\
\hline \multicolumn{8}{|l|}{ Marital status } \\
\hline Married & 446 & 56 & 148 & 53 & 594 & 55 & \multirow{4}{*}{0.5725} \\
\hline Single & 169 & 21 & 65 & 23 & 234 & 22 & \\
\hline Separated/divorced & 60 & 7 & 16 & 6 & 76 & 7 & \\
\hline Widow & 127 & 16 & 49 & 18 & 176 & 16 & \\
\hline \multicolumn{8}{|l|}{ Educational level } \\
\hline Illiterate & 91 & 12 & 45 & 17 & 136 & 13 & \multirow{5}{*}{0.0129} \\
\hline Incomplete primary education & 319 & 41 & 118 & 43 & 437 & 42 & \\
\hline Complete primary education & 138 & 18 & 57 & 21 & 195 & 19 & \\
\hline High school & 169 & 22 & 44 & 16 & 213 & 20 & \\
\hline College education & 51 & 7 & 8 & 3 & 59 & 6 & \\
\hline \multicolumn{8}{|l|}{ Source of referral } \\
\hline SUS & 441 & 64 & 180 & 75 & 621 & 67 & \multirow[t]{2}{*}{0.0020} \\
\hline Non-SUS & 248 & 36 & 61 & 25 & 309 & 33 & \\
\hline
\end{tabular}

SUS: Unified Health System.

SUS: Sistema Único de Saúde. 
source of referral $(p=0.0020)$ variables mentioned above showed statistical significance.

Regarding clinical variables, it was observed that in 378 cases (49\%), which comprised $53 \%$ of the total number of deaths, the primary tumor location was concentrated in the breast, with no other specifications (NOS). This item reflects the incompleteness of existing data in the medical files. Most tumors (51\%) showed left laterality, which covered $49 \%$ of deaths, while right laterality happened in $49 \%$ of cases and comprised $51 \%$ of deaths. Only $3 \%$ of women were reported to have more than one type of primary tumor, and 3\% of all deaths occurred in this category. Predominance $(86 \%)$ of the invasive ductal carcinoma histological type was identified, which comprised $91 \%$ of deaths. No association was observed between the primary tumor location, laterality and presence of more than one type of primary tumor and the histological type $(\mathrm{p}=0.6341, \mathrm{p}=0.5200, \mathrm{p}=0.6469$ and $\mathrm{p}=0.0652$, respectively). These data are not presented in Table 2 .

As shown in Table 2, there was a predominantly positive result for estrogen receptors $(69 \%)$ and progesterone receptors $(65 \%)$; $55 \%$ and $51 \%$ of all deaths occurred in these categories, respectively, compared with women who obtained a negative result ( $\mathrm{p}=0.0001$ for both variables). For tumor markers, it was identified that $78 \%$ of cases of c-erb-B-2

Table 2 - Distribution of deaths according to clinical variables of women diagnosed with breast cancer and treated at Santa Rita de Cássia Hospital from January 2000 to December 2005.

Tabela 2 - Distribuição dos óbitos segundo variáveis clínicas das mulheres com câncer de mama diagnosticadas e atendidas no Hospital Santa Rita de Cássia no período de janeiro de 2000 a dezembro de 2005.

\begin{tabular}{|c|c|c|c|c|c|c|c|}
\hline \multirow{3}{*}{ Categories } & \multicolumn{6}{|c|}{ Patient's situation } & \multirow{3}{*}{$\mathrm{p}$-value } \\
\hline & \multicolumn{2}{|c|}{ Non-death } & \multicolumn{2}{|c|}{ Death } & \multicolumn{2}{|c|}{ Total } & \\
\hline & $\mathrm{n}$ & $\%$ & $\mathrm{n}$ & $\%$ & $\mathrm{n}$ & $\%$ & \\
\hline \multicolumn{8}{|l|}{ Estrogen receptor } \\
\hline Positive & 509 & 74 & 122 & 55 & 631 & 69 & 0.0001 \\
\hline Negative & 181 & 26 & 99 & 45 & 280 & 31 & \\
\hline \multicolumn{8}{|c|}{ Progesterone receptor } \\
\hline Positive & 477 & 69 & 113 & 51 & 590 & 65 & 0.0001 \\
\hline Negative & 210 & 31 & 109 & 49 & 319 & 35 & \\
\hline \multicolumn{8}{|c|}{ c-erbB-2 tumor marker } \\
\hline Positive & 113 & 18 & 67 & 33 & 180 & 22 & 0.0001 \\
\hline Negative & 500 & 82 & 135 & 67 & 635 & 78 & \\
\hline \multicolumn{8}{|l|}{ P53 tumor marker } \\
\hline Positive & 105 & 21 & 58 & 34 & 163 & 25 & 0.0011 \\
\hline Negative & 386 & 79 & 113 & 66 & 499 & 75 & \\
\hline \multicolumn{8}{|c|}{ Number of metastases } \\
\hline None & 738 & 92 & 81 & 29 & 819 & 75 & 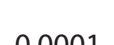 \\
\hline One & 46 & 6 & 128 & 46 & 174 & 16 & 0.0001 \\
\hline More than one & 22 & 2 & 71 & 25 & 93 & 9 & \\
\hline \multicolumn{8}{|l|}{ Recurrence } \\
\hline Yes & 25 & 3 & 49 & 18 & 74 & 7 & 0.0001 \\
\hline No & 775 & 97 & 231 & 82 & 1006 & 93 & \\
\hline \multicolumn{8}{|l|}{ Staging } \\
\hline I & 253 & 32 & 17 & 6 & 270 & 25 & \\
\hline II & 404 & 50 & 81 & 29 & 485 & 45 & 0.0001 \\
\hline III & 130 & 16 & 110 & 39 & 240 & 22 & \\
\hline IV & 19 & 2 & 72 & 26 & 91 & 8 & \\
\hline
\end{tabular}


showed negative results, in which $67 \%$ consisted of all deaths $(\mathrm{p}=0.0001)$. A similar situation occurred in the women who had negative P53 tumor marker (75\%) as $66 \%$ of deaths happened in this category $(\mathrm{p}=0.0011)$. In the 1,006 cases in which no relapse was observed, 231 deaths (82\% of the total) $(\mathrm{p}=0.0001)$ were verified. It was observed that $71 \%$ of all deaths occurred in the 267 patients with metastases, of which 128 presented more than one location and represented $46 \%$ of all deaths $(\mathrm{p}=0.0001)$. Regarding the clinical stage of the tumor at diagnosis, there was a higher frequency in stage II and $39 \%$ of deaths occurred in stage III ( $p=0.0001)$.

When analyzing the occurrence of deaths in each stage (Graph 1), it appears that the percentage of patients alive decreases with the progression of the disease. About $93.70 \%$ of patients diagnosed in stage I and $20.88 \%$ of patients diagnosed in stage IV remained alive.

Regarding the variables of diagnosis, the histology of the primary tumor was identified as a basis for establishing the diagnosis in all cases and, therefore, no statistical significance was observed. The distribution of categories was as follows: undiagnosed and untreated; diagnosed and untreated; diagnosed and treated. All categories had similar results; however, statistical relationship was found in the 116 deaths $(41 \%)$ concentrated in the diagnosed and untreated category. It should be noted that these variables are not shown in Table 2 .

Table 3 shows the crude and adjusted odds ratio calculated through the logistic regression model of the variables that were statistically significant (considering a level of 0.10). After the adjustment, only the following variables maintained statistical significance: source of referral $(\mathrm{p}=0.014$, $\mathrm{OR}=2.38)$, $\mathrm{c}$-erb-B-2 tumor marker ( $\mathrm{p}=0.027, \mathrm{OR}=2.03)$, stage III and IV $(\mathrm{p}=0.001, \mathrm{OR}=6.89$ and $\mathrm{OR}=17.13$, respectively), metastasis $(\mathrm{p}=0.001, \mathrm{OR}=18.23)$ and recurrence $(\mathrm{p}=0.010, \mathrm{OR}=3.53)$.

\section{Discussion}

Considering that, of the sociodemographic variables, only education level

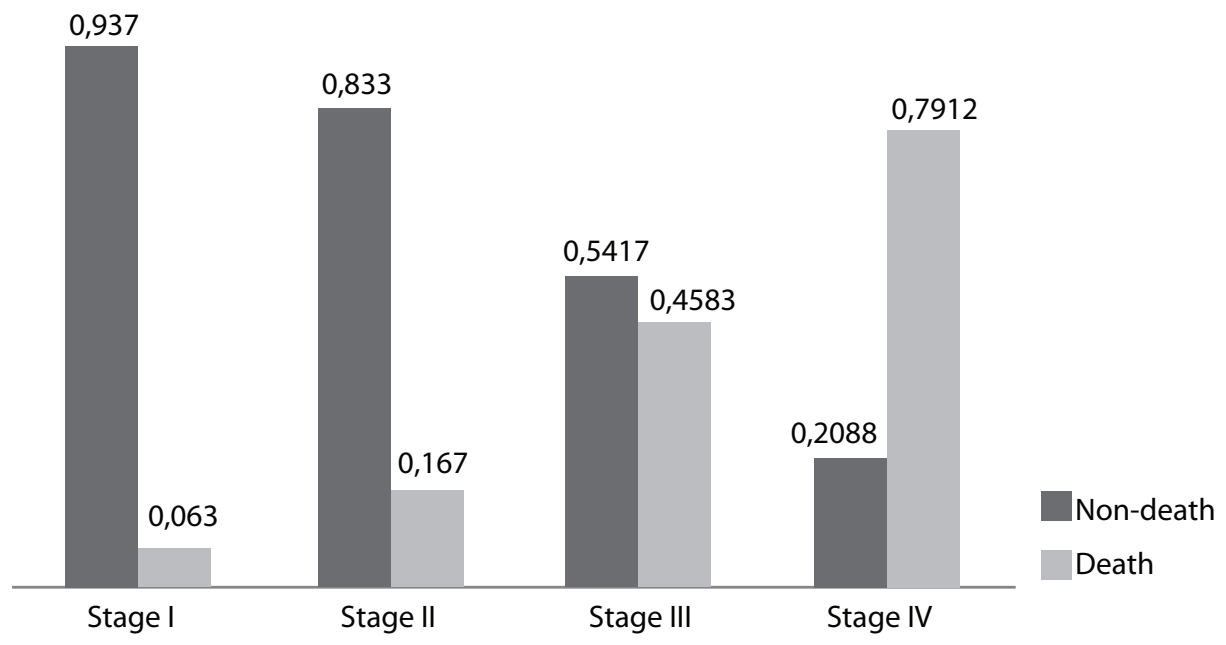

Graph 1 - Tumor stage at diagnosis of women diagnosed with breast cancer and treated at Santa Rita de Cássia Hospital in the period of January, 2000, through December, 2005.

Gráfico 1 - Estadiamento do tumor no momento do diagnóstico das mulheres com câncer de mama diagnosticadas e atendidas no Hospital Santa Rita de Cássia no período de janeiro de 2000 a dezembro de 2005. 
Table 3 - Crude and adjusted odds ratios of variables that showed statistical significance for women diagnosed with breast cancer and treated at Santa Rita de Cássia Hospital from January 2000 to December 2005.

Tabela 3 - Oddsratio brutos e ajustados das variáveis que apresentaram significância estatística das mulheres com câncer de mama diagnosticadas e atendidas no Hospital Santa Rita de Cássia no período de janeiro de 2000 a dezembro de 2005.

\begin{tabular}{|c|c|c|c|c|c|c|c|c|}
\hline \multirow{2}{*}{ Categories } & \multicolumn{4}{|c|}{ Crude OR } & \multicolumn{4}{|c|}{ Adjusted OR } \\
\hline & $p$-value & OR & IL 95\% & SL 95\% & $p$-value & OR & LI 95\% & LS 95\% \\
\hline \multicolumn{9}{|l|}{ Educational level } \\
\hline Illiterate & 0.006 & 3.15 & 1.38 & 7.20 & 0.517 & 1.86 & 0.28 & 12.28 \\
\hline Incomplete primary education & 0.030 & 2.36 & 1.09 & 5.12 & 0.773 & 1.31 & 0.21 & 8.07 \\
\hline Complete primary education & 0.019 & 2.63 & 1.18 & 5.90 & 0.670 & 1.50 & 0.23 & 9.79 \\
\hline High school & 0.223 & 1.66 & 0.73 & 3.75 & 0.759 & 1.34 & 0.20 & 8.90 \\
\hline College education & & 1.00 & & & & 1.00 & & \\
\hline \multicolumn{9}{|l|}{ Source of referral } \\
\hline SUS & 0.003 & 1.66 & 1.19 & 2.31 & 0.014 & 2.38 & 1.20 & 4.75 \\
\hline Non-SUS & & 1.00 & & & & & & \\
\hline \multicolumn{9}{|l|}{ Estrogen receptor } \\
\hline Positive & 0.001 & 0.44 & 0.32 & 0.60 & 0.537 & 0.77 & 0.33 & 1.77 \\
\hline Negative & & 1.00 & & & & 1.00 & & \\
\hline \multicolumn{9}{|l|}{ Progesterone receptor } \\
\hline Positive & 0.001 & 0.46 & 0.34 & 0.62 & 0.237 & 0.60 & 0.26 & 1.39 \\
\hline Negative & & 1.00 & & & & 1.00 & & \\
\hline \multicolumn{9}{|l|}{ c-erbB-2 tumor marker } \\
\hline Positive & 0.001 & 2.20 & 1.54 & 3.14 & 0.027 & 2.03 & 1.08 & 3.78 \\
\hline Negative & & 1.00 & & & & 1.00 & & \\
\hline \multicolumn{9}{|l|}{ P53 tumor marker } \\
\hline Positive & 0.001 & 0.53 & 0.36 & 0.78 & 0.579 & 1.19 & 0.64 & 2.24 \\
\hline Negative & & 1.00 & & & & 1.00 & & \\
\hline \multicolumn{9}{|l|}{ Staging } \\
\hline I & & 1.00 & & & & 1.00 & & \\
\hline ॥ & 0.001 & 2.98 & 1.73 & 5.15 & 0.149 & 1.97 & 0.78 & 4.97 \\
\hline III & 0.001 & 12.59 & 7.24 & 21.89 & 0.001 & 6.89 & 2.69 & 17.64 \\
\hline IV & 0.001 & 56.40 & 27.87 & 114.11 & 0.001 & 17.13 & 5.27 & 55.66 \\
\hline \multicolumn{9}{|l|}{ Metastases } \\
\hline Yes & 0.001 & 26.66 & 18.63 & 38.16 & 0.001 & 18.23 & 10.04 & 33.10 \\
\hline No & & 1.00 & & & & 1.00 & & \\
\hline \multicolumn{9}{|l|}{ Recurrence } \\
\hline Yes & 0.001 & 6.58 & 3.97 & 10.88 & 0.010 & 3.53 & 1.36 & 9.15 \\
\hline No & & 1.00 & & & & 1.00 & & \\
\hline
\end{tabular}

SUS: Unified Health System; IL: Inferior Limit; SL: Superior Limit; OR: Odds Ratio.

SUS: Sistema Único de Saúde; LI: Limite Inferior; LS: Limite Superior; OR: Odds Ratio. 
and source of referral were statistically significant, the relationship between low education and mortality was also observed in a study in Pará, where $60.11 \%$ of the deaths occurred in illiterate women who had only primary education (complete and incomplete), and $3.42 \%$ of deaths occurred in women with college education ${ }^{10}$. While in this study, illiterate patients presented a 3.15 times greater risk of death compared to those who had college education, in Santa Catarina, women with complete primary education showed a 3.76 times greater risk of death when compared to patients with college education ${ }^{11}$. Corroborating these findings, the Brazilian Cancer Institute has identified a tendency of decrease in the risk of death associated with a higher level of education ${ }^{12}$.

Regarding the source of referral, higher incidence of deaths in patients referred from SUS finds congruence with other researches ${ }^{11,12}$. The statistical significance of this variable and of the level of education refers to studies that relate a socioeconomic pattern to the progress of the disease ${ }^{13,14}$. A research on the factors related to primary prevention found that performing clinical breast examination, mammography and gynecological consultation were associated with higher social classes ${ }^{13}$.

It can be inferred that low educational level is an obstacle to secondary prevention of breast cancer, in relation to the practice of self-examination and to search by women of health services that perform clinical breast examinations and mammography. The issue of access to health care must be highlighted, because once low education level hinders the adoption of actions for an early diagnosis, it becomes essential to having public devices that facilitate access of this population to SUS.

Mortality associated with the expressive presence of estrogen and progesterone receptors disagrees with studies in which their presence represents a decrease in the risk of death $^{12,14}$. According to the literature, double negative status is associated with the patients' poor survival rate ${ }^{15-17}$. The expressive presence of c-erbB-2 tumor marker can be related to a poor survival rate in other studies, as well as a positive for p53 tumor markers can be associated with worse prognosis ${ }^{18-20}$. In this research, however, the opposite was verified, with the expression of receptors being associated with the greater number of deaths and the absence of both tumor markers related to higher mortality. It is worth noting that only 911, 909, 815 and 662 of the cases had any information on estrogen receptors, progesterone receptors and tumor markers c-erbB-2 and p53, respectively. Other authors suggest that information on the expression of receptors would not be a prognostic factor, but a predictive factor ${ }^{21,22}$. It is also stated that better prognosis associated with positive estrogen receptor compared to negative receptor becomes a residual difference after five years of survival ${ }^{23}$.

In this study, metastasis occurred in $25 \%$ of women, whereas others have found an incidence of $6-7 \%^{10,11,18}$. This variable is related to the mortality of patients, as the TNM (Tumor, Node and Metastasis) Classification of Malignant Tumors considers its existence to determine disease progression ${ }^{24}$. Regarding the progression of disease, it is noteworthy that there is a higher incidence of diagnosed patients with early stages (I and II) in which cases, according to literature, better prognosis can be identified when compared to more advanced stages ${ }^{11,18,25}$.

As a limitation of the study, it was chosen not to assess the type of treatment and performance status of the patients. In some cases, patients were diagnosed with breast tumor and received their first treatment in other hospitals, and information regarding the time of treatment was not identified. On performance status, assessment of the welfare of patients was not performed by the group 
of professionals, or it was not described in the files, which did not provide sufficient information for researchers in this study to assess this data accurately.

Given the above, it becomes evident that greater risk associated with low educational level, advanced stage and metastasis point to the chance of late diagnosis in women with low education, which reinforces the need for strategies that facilitate the access of this population to health institutions, especially with regard to SUS, since an increased risk for patients who are referred from this system was also observed. There is a notable importance of further studies to identify gaps in access to the health care system for advanced stages, so that public policies can be reorganized with a focus on the early diagnosis of breast cancer.

\section{References}

1. World Health Organization. Global action against cancer. Geneva; 2003.

2. World Health Organization. World cancer report 2008. Geneva; 2008.

3. Ministério da Saúde (BR). DATASUS. Cadernos de Informação de Saúde [Internet]. Rio de Janeiro (RJ); 2010 Disponível em: http://tabnet.datasus.gov.br/tabdata/ cadernos/cadernosmap.htm?saude=http\%3A\%2F\%2Ftabnet. datasus.gov.br\%2Ftabdata\%2Fcadernos\%2Fcadernosmap. htm\&botaook=OK\&obj=http\%3A\%2F\%2Ftabnet.datasus.gov. br\%2Ftabdata\%2Fcadernos\%2Fcadernosmap.htm. (Acessado em 12 de outubro de 2011).

4. Brasil. Ministério da Saúde. Instituto Nacional do Câncer. Estimativas 2012: incidência de câncer no Brasil. Rio de Janeiro, RJ: INCA; 2011.

5. Araujo SDTA. Mortalidade, por câncer de mama, de mulheres com idade igual e superior a 50 anos - Estado de São Paulo 1979 a 1997 [dissertação de mestrado]. São Paulo: Faculdade de Saúde Pública da Universidade de São Paulo; 2000.

6. Gonçalves ME, Barbosa AB. Mortalidade e morbidade por câncer de mama feminino na região Sudeste do Brasil (segundo UF's): uma análise para 1998 e 2003. In: XV Encontro Nacional de Estudos Populacionais, ABEP; 2006 set 18-22; Caxambú (MG), Brasil.

7. Felix JD, Castro DS, Amorim MHC, Zandonade E. Tendência de Mortalidade por câncer de mama em mulheres no estado do Espírito Santo, no período de 1980 a 2007. Rev Bras Cancerol 2011: 57(2): 159-166.

8. Brasil. Ministério da Saúde. Portaria no 741 de 19 de dezembro de 2005 Brasilia, DF; 2005. Brasilia, DF; 2005. Disponível em: http://bvsms.saude.gov.br/bvs/saudelegis/ sas/2005/prt0741_19_12_2005.html. (Acessado em $16 \mathrm{de}$ outubro de 2011).
9. Brasil. Ministério da Saúde. Portaria no 196 de 10 de outubro de 1996 Brasilia, DF; 1996. Brasilia, DF; 1996. Disponível em: http://conselho.saude.gov.br/resolucoes/reso_96.htm. (Acessado em 20 de outubro de 2011).

10. Pereira WMM. Mortalidade e sobrevida por câncer de mama no estado Pará [dissertação de mestrado]. Pará: Escola Nacional de Saúde Pública. Universidade Federal do Pará; 2001.

11. Schneider IJC. Estudo de sobrevida em mulheres com câncer de mama em Santa Catarina [dissertação de mestrado]. Santa Catarina: Universidade Federal de Santa Catarina; 2008.

12. Mendonça GAS, Silva AM, Caula, Wagner M. Características tumorais e sobrevida de cinco anos em pacientes com câncer de mama admitidas no Instituto Nacional de Câncer, Rio de Janeiro, Brasil. Cad Saúde Pública 2004; 20(5): 1232-9.

13. Sclowitz ML, Menezes AM, Gigante DP, Tessaro S. Condutas na prevenção secundária do câncer de mama e fatores associados. Rev Saúde Pública 2005; 39(3): 340-9.

14. Hussain Sk, Lenner P, Sundquist J, Hemminki K. Influence of education level on cancer survival in Sweden. Ann Oncol 2008; 19(1): 156-62.

15. Bauer KR, Brown M, Cress RD, Parise CA, Caggiano V. Descriptive analysis of estrogen receptor (ER)-negative, progesteron receptor (PR)-negative, and HER2-negative invasive breast cancer, the so-called triple-negative phenotype: a population-based study from the California cancer Registry. Cancer 2007; 109(9): 1721-8.

16. Onitilo AA, Engel JM, Greenlee RT, Mukesh BN. Breast cancer subtypes based on ER/PR and Her2 expression: comparision of clinicopathologic features and survival. Clin Med Res 2009: 7(1-2): 4-13. 
17. Rakha EA, El-Sayed ME, Green AR, Lee AH, Robertson JF, Ellis IO. Prognostic markers in triple-negative breast cancer. Cancer 2007; 109(1): 25-32.

18. Moraes AB, Zanini RR, Turchiello MS, Riboldi J, Medeiros LR. Estudo da sobrevida de pacientes com câncer de mama atendidas no hospital da Universidade Federal de Santa Maria, Rio Grande do Sul, Brasil. Cad Saúde Pública 2006; 22(10): 2219-28.

19. Cooke T, Reeves J, Lanigan A, Stanton P. HER2 as a prognostic and predictive marker for breast cancer. Ann Oncol 2001; 12(Suppl 1): S23-8.

20. Berry DA, Cirrincione C, Henderson IC, Citron ML, Budman DR, Goldstein LJ, et al. Estrogen-receptor status and outcomes of modern chemotherapy for patients with node positive breast cancer. JAMA 2006; 295(14): 1658-67.

21. Bentzon N, During M, Rasmussen BB, Mouridsen H, Kroman N. Prognostic effect of estrogen receptor status across age in primary breast cancer. Int J Cancer 2008; 122(5): 1089-94.
22. Goldhirsch A, Glick JH, Gelber RD, Coates AS, Thurlimann B, Senn HJ, et al. Meeting highlights: international expert consensus on the primary therapy of early breast cancer 2005. Ann Oncol 2005; 16(10): 1569-83.

23. Simão TA, Ribeiro FS, Amorim LM, Albano RM, AndradaSerpa MJ, Cardoso LE, et al. TP53 mutations in breast cancer tumors of patients from Rio de Janeiro, Brazil: association with risk factors and tumor characteristics. Int J Cancer 2002; 101(1): 69-73.

24. Brasil. Secretaria Nacional de Assistência à saúde. Instituto Nacional do Câncer. TNM: classificação de tumores malignos. 6.ed. Rio de Janeiro, RJ: INCA; 2004.

25. Cintra JRD, Guerra MR, Bustamante-Teixeira MT. Sobrevida específica de pacientes com câncer de mama não-metastático submetidas à quimioterapia adjuvante. AMB Rev Assoc Med Bras 2008; 54(4): 339-46.

Received on: 04/13/12 Final version presented on: $12 / 12 / 12$ Accepted on: 01/15/13 